\section{Retaining the Benefits of Matriconditioning by Controlled Drying of Snap Bean Seeds}

\author{
Wlodzimierz Ptasznik' and Anwar A. Khan ${ }^{2}$ \\ Department of Horticultural Sciences, New York State Agricultural Experiment \\ Station, Cornell University, Geneva, NY 14456
}

Additional index words. Phaseolus vulgaris, osmoconditioning, seed quality, electrolyte leakage, seed performance

\begin{abstract}
The effects of various drying conditions on seed quality and performance of matriconditioned 'Bush Blue Lake 47' snap bean (Phaseolus vulgaris L.) seeds were studied. An exponential model based on the Page equation provided a good fit $\left(R^{2}=0.9\right)$ to changes in moisture content during drying. Drying matriconditioned seeds with high initial moisture content $(47.2 \%)$ for 5 to 6 hours at $35 \mathrm{C}, 30 \%$ to $35 \%$ relative humidity, and 0.7 to $1.4 \mathrm{~m} \cdot \mathrm{s}^{-1}$ air velocity ( $\mathrm{v}$ ) retained, and in some cases augmented, the benefits derived from conditioning. Matriconditioning greatly reduced electrolyte leakage (34.3 vs. 94.7 $\mu \mathrm{S} \cdot \mathrm{cm}^{-1} \cdot \mathrm{g}^{-1}$ for nontreated seeds); drying to $15 \%$ moisture content at 0.7 or $1.4 \mathrm{~m} \cdot \mathrm{s}^{-1} \mathrm{v}$ moderately increased the leakage rate $\left(59.1\right.$ to $\left.60.9 \mathrm{vs} .34 .3 \mu \mathrm{S} \cdot \mathrm{cm}^{-1} \cdot \mathrm{g}^{-1}\right)$, while drying at $0.02 \mathrm{~m} \cdot \mathrm{s}^{-1} \mathrm{v}$ (ambient) increased the rate to that of nontreated seeds. The leakage rate remained low $\left(43.6\right.$ to $\left.50.8 \mu \mathrm{S} \cdot \mathrm{cm}^{-1} \cdot \mathrm{g}^{-1}\right)$ in matriconditioned seeds dried to $22 \%$ moisture content at all air velocities. In growth-chamber studies, rapidly drying matriconditioned seeds to $15 \%$ moisture content at $1.4 \mathrm{~m} \cdot \mathrm{s}^{-1} \mathrm{v}$ improved the emergence percentage over that of nontreated seeds, increased the shoot fresh and dry weight over that of nontreated and nondried matriconditioned seeds, and increased the shoot fresh weight over that of seeds dried at 0.02 or $0.7 \mathrm{~m} \cdot \mathrm{s}^{-1} \mathrm{v}$. Drying matriconditioned seeds to $15 \%$ moisture content at 0.7 $\mathbf{m} \cdot \mathbf{s}^{-1} \mathbf{v}$ improved plant fresh weight over that produced by nontreated seeds. Rapid drying to $22 \%$ moisture content at 1.4 or $0.7 \mathrm{~m} \cdot \mathrm{s}^{-1} \mathrm{v}$ improved only shoot fresh weight over that of nontreated seeds. In a 1992 field planting, percent emergence of matriconditioned seeds dried at 0.7 or $1.4 \mathrm{~m} \cdot \mathrm{s}^{-1} \mathrm{v}$ was similar to that of nondried matriconditioned seeds and higher than that of nontreated seeds. No significant differences were noted in plant yield among the treatments.
\end{abstract}

Osmoconditioning (osmotic priming) seeds in a liquid medium has been used to shorten germination time, synchronize emergence, and improve stand and yield (Bradford, 1986; Heydecker and Coolbear, 1977; Khan et al., 1978, 1992). Recently, moist, solid carriers [vermiculite, expanded calcined clay, MicroCel E (a synthetic calcium silicate) (Manville, Denver)] with matric properties have been used to matricondition vegetable and flower seeds before planting (Bennett and Waters, 1984, 1987; Khan, 1992; Khan et al., 1990; Kubik et al., 1988). Empirical approaches have been used to dry seeds after conditioning, but little or no attention has been given to the influences of factors such as low vs. high relative humidity $(\mathrm{RH})$, low vs. high air velocity (v), slow vs. rapid drying, high vs. low

Received for publication 30 Nov. 1992. Accepted for publication 14 May 1993. This research was supported in part by grants from the New York Snap Bean Research Association and the Alfred Jurzykowski Foundation. We gratefully acknowledge the gifts of MicroCel E from Manville, Denver, and of snap bean seeds from Asgrow Seed Co., Kalamazoo, Mich. The cost of publishing this paper was defrayed in part by the payment of page charges. Under postal refutations, this paper therefore must be hereby marked advertisement solely to indicate this fact.

${ }^{1}$ Visiting Fellow.

${ }^{2}$ Professor; to whom reprint requests should be addressed. This neglect may have caused large decreases in the benefits derived from conditioning.

Small vegetable seeds have been air-dried at 15 to $32 \mathrm{C}$ or at room temperature, usually for extended periods, before they are stored, sown, or planted. A fluidized drying procedure in which $\mathrm{RH}$, air velocity, and temperature were regulated (Nienow et al., 1991) was used recently to dry leek (Allium porrum L.) seeds. Few studies have been conducted on osmoconditioning or matriconditioning large vegetable seeds (e.g., snap bean) and cereals, and even fewer have been conducted on drying after conditioning. Air-drying osmoconditioned soybean [Glycine max (L.) Merr.] seeds at $25 \mathrm{C}$ for $24 \mathrm{~h}$ retained, to a large extent, the benefits of conditioning as determined by emergence in a soil mix at a suboptimal temperature (8C) in a growth chamber, but not in early field plantings (Khan et al., 1980/81; Knypl and Khan, 1981). Sweet corn (Zea mays L.) seeds, matriconditioned with calcined clay and dried in a chamber at $25 \mathrm{C}$ and $45 \% \mathrm{RH}$, had a higher germination percentage in a cold medium than nonconditioned seeds (Parera

Two distinct approaches have been used to condition and dry large seeds. When using calcined clay as a solid carrier, sweet corn seeds are dried to a low moisture content at the conditioning temperature (Kubik et al., 1988; temperature, and final seed moisture content. and Cantliffe, 1992a).
Parera and Cantliffe, 1992b); in matriconditioning with Micro-Cel $\mathrm{E}$ and vermiculite, conditioning is separate from the drying process (Khan and Ptasznik, 1992; Khan et al., 1990). In a recent study, the effectiveness of drying matriconditioned snap bean seeds under various conditions was evaluated by a cold germination test on rolled paper towels; the optimal drying conditions were 33.9 to $35.9 \mathrm{c}$, $30 \%$ to $40 \% \mathrm{RH}$, and 0.7 to $1.4 \mathrm{~m} \cdot \mathrm{s}^{-1} \mathrm{v}$ (Ptasznik et al., 1992).

In this report we describe 1) the process of drying matriconditioned snap bean seeds using a modified exponential model and 2) the influence of various drying conditions on the quality and performance of matriconditioned seeds in growth-chamber and field studies under suboptimal growing conditions.

'Bush Blue Lake 47' snap bean seeds (1991 harvest) were used in this study. The seeds were stored at $\approx 7 \mathrm{C}$ and $28 \% \mathrm{RH}$, and small amounts were removed as needed.

Seeds with an initial moisture content of $\approx 13 \%$ were matriconditioned with moist Micro-Cel E. The conditioning mixture consisted of 1 seeds : 0.4 Micro-Cel E : 1.3 water (by weight). Seeds were matriconditioned in loosely covered glass jars for 2 days at $15 \mathrm{C}$ and $\approx 45 \% \mathrm{RH}$. After matriconditioning, seeds were separated from the Micro-Cel E by sieving. The mean moisture content of the seeds after 2 days of conditioning was $47.2 \%$ (wet basis).

Seeds were dried in specially constructed equipment that permitted us to control and monitor temperature and air velocity carefully (Ptasznik et al., 1992). The equipment was located in a chamber (Jewett Refrigerator Co., Buffalo, N.Y.) that permitted us to control RH and ambient air temperature precisely. $\mathrm{RH}$ in the chamber was determined using an etchedstem thermometer (model 1328; Taylor Instrument Co., Rochester, N. Y.) and humidity tables. Matriconditioned seeds were dried in thin layers at $35 \mathrm{C}$ and $20 \%, 40 \%, 60 \%$, and $80 \%$ RH. Air velocity varied from 0.02 (arubient) to $1.4 \mathrm{~m} \cdot \mathrm{s}^{-1}$. Water loss from the matriconditioned seeds during drying was determined by weighing them every hour during the first $12 \mathrm{~h}$ of drying and every $12 \mathrm{~h}$ subsequently (Ptasznik at al., 1992).

To determine initial and final moisture content of the seeds, Grabe's (1989) air-oven method was used. All seed samples were ground and dried for 2 hat 130C. The process was modified for seeds with initial moisture content $>17 \%$ (wet basis). To facilitate grinding, these seeds were predried for 5 to $10 \mathrm{~min}$ at $130 \mathrm{C}$ to reduce the moisture content, and, after a 2-h break at room temperature, ground and redried for $2 \mathrm{~h}$ at $130 \mathrm{C}$.

Changes in seed moisture content found during drying in a thin layer were predicted using a modified exponential model (Table 1) (Huizhen and Morey, 1984; Misra and Brooker, 1980) based on the Page equation: $M R=\exp$ $\left(-\mathrm{kt}^{\mathrm{n}}\right)$, where $\mathrm{MR}=$ moisture ratio, $\mathrm{k}$ and $\mathrm{n}=$ estimated parameters, and $\mathrm{t}=$ drying time (min). The model was fitted by Murquardt's method using SAS's NLIN procedure (SAS Institute, 1990).

To determine electrical conductivity (EC) 
Table 1. Drying conditions and constant values in the Page equation evaluated by Murquardt's method.

\begin{tabular}{|c|c|c|c|c|}
\hline \multicolumn{2}{|c|}{$\begin{array}{c}\text { Drying conditions } \\
\text { at } 35 \mathrm{C}\end{array}$} & & & \multirow{3}{*}{$\begin{array}{c}\text { Equilibrium moisture } \\
\text { of snap bean seeds } \\
(\%)\end{array}$} \\
\hline \multirow{2}{*}{$\begin{array}{l}\text { Relative } \\
\text { humidity } \\
(\%)\end{array}$} & \multirow[b]{2}{*}{$\begin{array}{l}\text { Velocity } \\
\left(\mathrm{m} \cdot \mathrm{s}^{-1}\right)\end{array}$} & \multicolumn{2}{|c|}{ Constant } & \\
\hline & & $\begin{array}{l}\text { Drying } \\
\text { (min) }\end{array}$ & Empirical & \\
\hline \multirow[t]{2}{*}{20} & 0.02 & -0.000777 & 1.10700 & 4.80 \\
\hline & 1.40 & -0.021270 & 0.74230 & 4.80 \\
\hline \multirow[t]{2}{*}{40} & 0.02 & -0.000455 & 1.14445 & 6.40 \\
\hline & 1.40 & -0.021880 & 0.73465 & 6.40 \\
\hline \multirow[t]{2}{*}{60} & 0.02 & -0.000062 & 1.35592 & 9.30 \\
\hline & 1.40 & -0.014675 & 0.79373 & 9.30 \\
\hline \multirow[t]{2}{*}{80} & 0.02 & -0.000024 & 1.39923 & 15.40 \\
\hline & 1.40 & -0.006793 & 0.88493 & 15.40 \\
\hline
\end{tabular}

in the seed leachate, nontreated, matriconditioned, and matriconditioned and dried (at $35 \mathrm{C}, 30 \% \mathrm{RH}$, and $1.4 \mathrm{~m} \cdot \mathrm{s}^{-1} \mathrm{v}$ ) seeds were rinsed for a few seconds with deionized water. Twenty-five seeds were soaked in $75 \mathrm{ml}$ deionized water for $20 \mathrm{~h}$ at $25 \mathrm{C}$ in light. Levels of electrolytes leached during soaking were determined by a digital conductivity meter (VWR, Rochester, N.Y.). EC was expressed in microSiemens per centimeter per gram of seeds.

Matriconditioned seeds that were dried to $15 \%$ (wet basis) moisture content at 35C, $30 \%$ $\mathrm{RH}$, and 0.02 to $1.4 \mathrm{~m} \cdot \mathrm{s}^{-1} \mathrm{v}$ and that performed optimally in a cold germination test (Ptasznik et al., 1992) were used. Eight nontreated, matriconditioned, and matriconditioned and dried seeds per row per plastic box $(35 \times 26 \times$ $11 \mathrm{~cm}$ ) in three replications (three boxes) were planted $1 \mathrm{~cm}$ deep in a 1 peat : 1 vermiculite mix, and seedling emergence was determined in a growth chamber set at $20 \mathrm{C}$ for $12 \mathrm{~h}$ in light, then at $10 \mathrm{C}$ in darkness. Top fresh and dry weights (dried for $48 \mathrm{~h}$ at 70C) were determined after 16 days. For field studies started on 1 May 1992, 100 seeds in five replications were planted in 6-m rows, $75 \mathrm{~cm}$ apart, $5 \mathrm{~cm}$ deep. The average maximum and minimum soil temperatures at $5 \mathrm{~cm}$ during the first 30 days after planting were 17 and $12 \mathrm{C}$, and, during the next 63 days before harvesting, 22 and 18C. Data were subjected to analysis of variance, and Duncan's multiple range test ( $\alpha$ $=0.05$ ) was used to determine mean comparisons of seedling emergence, EC, and plant yield.

The moisture content of snap bean seeds increased to $47.2 \%$ during 2 days of matriconditioning at $15 \mathrm{C}$, and moisture content increased little from 48 to $132 \mathrm{~h}$ (Fig. 1). It takes 2 to 4 days to matricondition snap bean seeds optimally (Khan et al., 1990).

Changes in seed moisture content in response to various drying conditions were highly predictable (Table 1, Fig. 2). The exponential model provided a very good fit $\left(R^{2}=0.9\right)$ to the experimental data, the curves under various drying conditions fitted the given equation. At $35 \mathrm{C}, 0.02 \mathrm{~m} \cdot \mathrm{s}^{-1} \mathrm{v}$, and $80 \% \mathrm{RH}$, snap bean seeds took the longest time to dry. The equilibrium moisture content of snap bean seeds is reported to be $15.4 \%$ at $35 \mathrm{C}$ and $80 \% \mathrm{RH}$ [American Society of Agricultural Engineers (ASAE), 1983], and it required $120 \mathrm{~h}$ to reach this moisture level (Fig. 2A). To obtain the same final moisture content at $60 \%, 40 \%$, and
$20 \% \mathrm{RH}$, drying time decreased to 34,20 , and $15 \mathrm{~h}$, respectively (Fig. 2A). The equilibrium moisture content for snap bean seeds at $60 \%$, $40 \%$, and $20 \% \mathrm{RH}$ at $35 \mathrm{C}$ is $9.3 \%, 6.4 \%$, and $4.8 \%$, respectively (ASAE, 1983).

To achieve $15 \%$ moisture content at $35 \mathrm{C}$, $0.7 \mathrm{~m} \cdot \mathrm{s}^{-1} \mathrm{v}$, and $80 \% \mathrm{RH}$, drying time was 35 $\mathrm{h}$ (Fig. 2B). This period was $\approx 3.5$ times shorter $\left(35\right.$ vs. $120 \mathrm{~h}$ ) than at $0.02 \mathrm{~m} \cdot \mathrm{s}^{-1} \mathrm{v}$. At $60 \%$, $40 \%$, and $20 \% \mathrm{RH}$, with temperature and air velocity remaining the same, drying time decreased to 11,8 , and $6 \mathrm{~h}$, respectively.

Drying was most rapid at $1.4 \mathrm{~m} \cdot \mathrm{s}^{-1} \mathrm{v}, 35 \mathrm{C}$, and $20 \% \mathrm{RH}$. To attain $15 \%$ final moisture content at $80 \%, 60 \%, 40 \%$, and $20 \% \mathrm{RH}$, drying times were $30,8.5,5.5$, and $5 \mathrm{~h}$ (Fig. $2 \mathrm{C})$. To attain a final moisture content of $15 \%$ at $0.02,0.7$, and $1.4 \mathrm{~m} \cdot \mathrm{s}^{-1} \mathrm{v}$ (at $20 \% \mathrm{RH}$ and $35 \mathrm{C}$ ), drying times were 15,6 , and $5 \mathrm{~h}$, respectively (Fig. 2D).

Electrolyte leakage patterns were similar in seeds dried to $15 \%$ or $22 \%$ moisture content (Fig. $3 \mathrm{~A}$ and B). The highest EC values (94.7 to $\left.100 \mu \mathrm{S} \cdot \mathrm{cm}^{-1} \cdot \mathrm{g}^{-1}\right)$ were found in nontreated seeds and the lowest values $\left(34.3 \mu \mathrm{S} \cdot \mathrm{cm}^{-1} \cdot \mathrm{g}^{-1}\right)$ in nondried matriconditioned seeds. Among the dried seed classes, those with $15 \%$ moisture content (Fig. 3A) had greater EC than those with $22 \%$ moisture content (Fig. 3B). $\mathrm{EC}$ in the leachates from matriconditioned seeds dried to $15 \%$ moisture content at 0.02 to $1.4 \mathrm{~m} \cdot \mathrm{s}^{-1} \mathrm{v}$ ranged from 59.1 to $90.3 \mu \mathrm{S} \cdot \mathrm{cm}^{-1} \cdot \mathrm{g}^{-1}$. EC values were 43.6 to $53.8 \mu \mathrm{S} \cdot \mathrm{cm}^{-1} \cdot \mathrm{g}^{-1}$ when seeds were dried to $22 \%$ moisture content at the same air velocities. A high EC (90.3 $\left.\mu \mathrm{S} \cdot \mathrm{cm}^{-1} \cdot \mathrm{g}^{-1}\right)$ similar to that of nontreated seeds was obtained when matriconditioned seeds were dried to $15 \%$ moisture content at 0.02 $\mathrm{m} \cdot \mathrm{s}^{-1} \mathrm{v}$. These data suggest that rapid drying to $15 \%$ moisture content may retain the benefits of matriconditioning by ensuring greater cellular integrity than slow drying. Drying at all air velocities seems to be less disruptive to the seed when drying progresses only to $22 \%$ instead of $15 \%$ moisture content, as revealed by the lower electrolyte leakage. However, planting seeds with high moisture content may render them highly susceptible to soil pathogens, particularly under cold, wet conditions (see below).

We previously reported, using a cold germination test, that the benefits of matriconditioning were best retained when the conditioned seeds were dried at $35 \mathrm{C}, 30 \%$ to $40 \%$ $\mathrm{RH}$, and 0.7 to $1.4 \mathrm{~m} \cdot \mathrm{s}^{-1} \mathrm{v}$ (Ptasznik et al.,

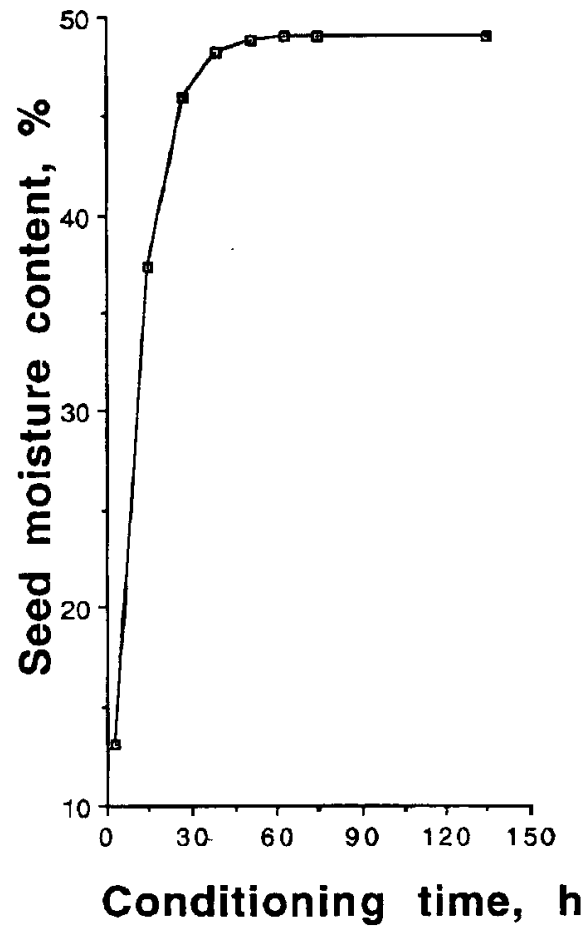

Fig. 1. Time course of water absorption by snap bean seeds during matriconditioning.

1992). These drying conditions also were effective in the present study, as shown by the fact that rapid drying retained the capacity for improved emergence and biomass production in a peat-vermiculite mix under controlled temperatures and in early field plantings under suboptimal temperatures.

When matriconditioned snap bean seeds were dried to a final moisture content of $15 \%$ (Fig. 4A) and 22\% (Fig. 4C), emergence began 1 to 2 days earlier than for the nontreated seeds. The percent emergence of matriconditioned seeds dried to $15 \%$ moisture content at $35 \mathrm{C}$ and $1.4 \mathrm{~m} \cdot \mathrm{s}^{-1} \mathrm{v}$ was higher than for nontreated seeds (Fig. 4A). Nondried matriconditioned seeds or those dried at 0.02 to $0.7 \mathrm{~m} \cdot \mathrm{s}^{-1} \mathrm{v}$, although showing a trend of increasing emergence, did not differ significantly from the nontreated seeds. Matriconditioned seeds dried to $22 \%$ moisture content at 0.02 to $1.4 \mathrm{~m} \cdot \mathrm{s}^{-1} \mathrm{v}$ did not differ significantly in percent emergence from nontreated or nondried matriconditioned seeds (Fig. 4C).

Matriconditioned seeds dried to $15 \%$ moisture content at 0.02 to $1.4 \mathrm{~m} \cdot \mathrm{s}^{-1} \mathrm{v}$ produced seedlings with higher fresh and dry weights than the nontreated seeds, while those dried at $1.4 \mathrm{~m} \cdot \mathrm{s}^{-1} \mathrm{v}$ produced higher seedling fresh and dry weights than the nondried matriconditioned seeds or those dried at lower air velocities (Fig. 4B). Matriconditioned seeds dried to $22 \%$ moisture content at 0.7 or $1.4 \mathrm{~m} \cdot \mathrm{s}^{-1} \mathrm{v}$ also produced seedlings with higher fresh weights than seedlings from nontreated seeds (Fig. 4D). Improved emergence and plant weight of seedlings from matriconditioned seeds dried rapidly to $15 \%$ moisture content maybe attributed to a greater resistance (compared to nondried or partially dried matriconditioned seeds) to the cold (20/10C day/night), wet 

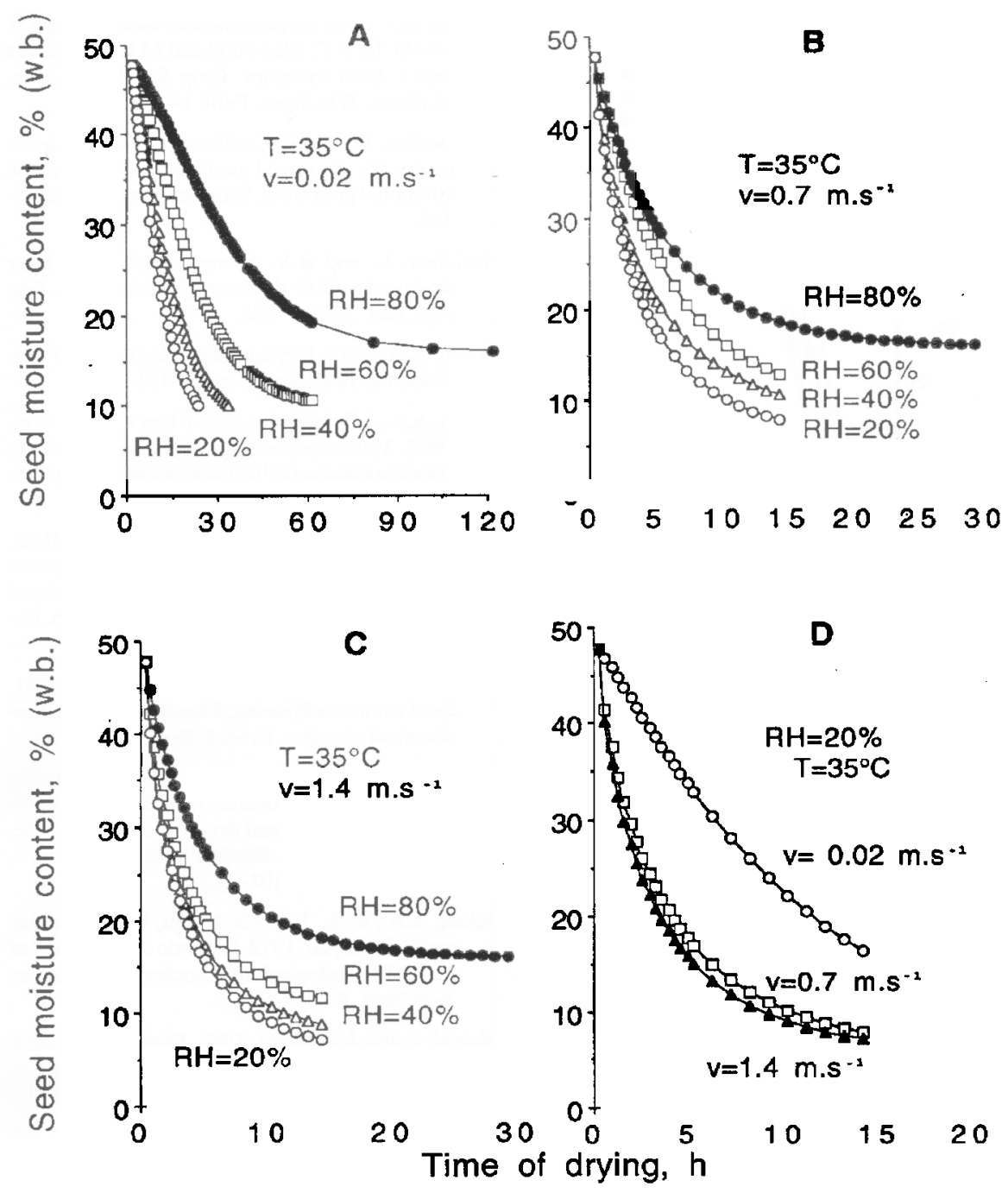

Fig. 2. Changes in moisture content of matriconditioned snap bean seeds during drying. (A) Temperature (T) $=35 \mathrm{C}$, air velocity $(\mathrm{v})=0.02 \mathrm{~m} \cdot \mathrm{s}^{-1} ;($ B $) \mathrm{T}=35 \mathrm{C}, \mathrm{v}=0.7 \mathrm{~m} \cdot \mathrm{s}^{-1} ;$ (C) $\mathrm{T}=35 \mathrm{C}, \mathrm{v}=1.4 \mathrm{~m} \cdot \mathrm{s}^{-1} ;$ (D) $\mathrm{T}=$ $35 \mathrm{C}$, relative humidity $(\mathrm{RH})=20 \%$.

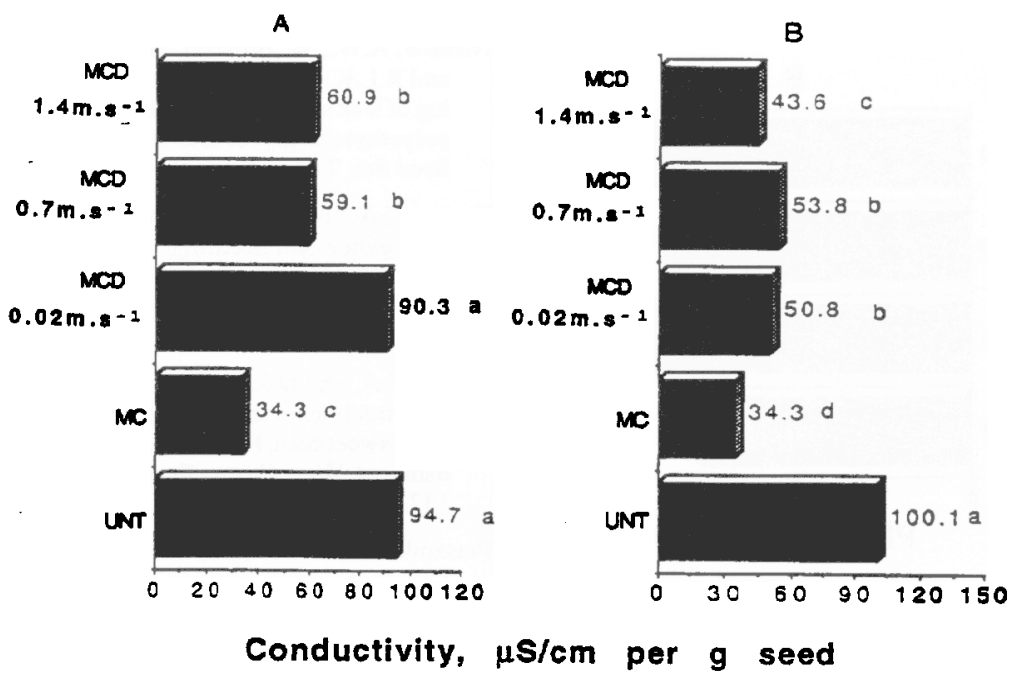

Fig. 3. Comparison of electrical conductivity of matriconditioned snap bean seeds dried to (A) $15 \%$ and $(B)$ $22 \%$ moisture content (wet basis) with that of nondried matriconditioned and nontreated seeds. Mean separation in A and B by analysis of variance and Duncan's multiple range test $(\alpha=0.05)$. UNT $=$ nontreated, $\mathrm{MC}=$ matriconditioned, $\mathrm{MCD}=$ matriconditioned and then dried. environment of the peat-vermiculite mix and to possible infestation of the mix with damping-off organisms.

In the 1 May 1992 field planting, matriconditioned and dried matriconditioned seeds had similar emergence percentages $(65 \%$ to $70 \%$ ), which were significantly higher than that $(53 \%)$ of nontreated seeds (Fig. 5A). However, no significant differences were found in plant yield among the various treatments (Fig. 5B). Although matriconditioning snap bean seeds can result in rapid emergence in early field plantings, it sometimes reduces (particularly under wet conditions) the final emergence compared to that of nontreated seeds. A seed treatment with fungicides and gibberellin during matriconditioning greatly improves final emergence (Khan and Ptasznik, 1992; Khan et al., 1992). It would be useful to determine the response of dried matriconditioned seeds to fungicides and hormones.

These data indicate that rapid and controlled drying may be essential for retaining the benefits of snap bean seed matriconditioning and, under the cold, wet conditions found during early plantings, may even augment the benefits of matriconditioning alone. The fact that rapid drying (with $\mathrm{RH}$ and air velocity constant) at $35 \mathrm{C}$ retains the benefits of matriconditioning more than slow drying at 25C (Khan and Ptasznik, 1992; Ptasznik et al., 1992) suggests that it may be necessary to select temperatures ideal for seed conditioning and drying. Effective matriconditioning of snap beans is achieved in 2 days at $15 \mathrm{C}$ and $\approx 45 \% \mathrm{RH}$, and optimal drying after matriconditioning is achieved at $35 \mathrm{C}$ (at 0.7 to 1.4 $\mathrm{m} \cdot \mathrm{s}^{-1} \mathrm{v}$ and $30 \%$ to $35 \% \mathrm{RH}$ ) in 5 to $6 \mathrm{~h}$.

Controlled, rapid drying of matriconditioned snap bean seeds to $15 \%$ moisture content at a moderately high temperature $(35 \mathrm{C})$, low RH (30\% to $35 \%)$, and high air velocity $\left(0.7\right.$ to $\left.1.4 \mathrm{~m} \cdot \mathrm{s}^{-1}\right)$ retains the benefits of matriconditioning, as evidenced by decreased electrolyte leakage and improved seed performance. In some cases, rapidly drying matriconditioned seeds can augment the benefits of matriconditioning. Drying time (fast vs. slow), final seed moisture content ( $15 \%$ vs. $22 \%$ ), and planting medium influence seed performance and plant yield. Drying matriconditioned seeds to low moisture content should facilitate handling, storage, transport, and planting operations.

\section{Literature Cited}

American Society of Agricultural Engineers. 1983. Agricultural engineers yearbook. vol. 30. Amer. Soc. Agr. Eng., St. Joseph, Mich. p. 298-299.

Bennett, M.A. and L. Waters, Jr. 1984. Influence of seed moisture on lima bean stand establishment and growth. J. Amer. Soc. Hort. Sci. 109:623626.

Bennett, M.A. and L. Waters, Jr. 1987. Seed hydration treatments for improved sweet corn germination and stand establishment. J. Amer. Soc. Hort. Sci. 112:45-49.

Bradford, K.J. 1986. Manipulation of seed water relations via osmotic priming to improve germination under stress conditions. HortScience 21:1105-1112. 


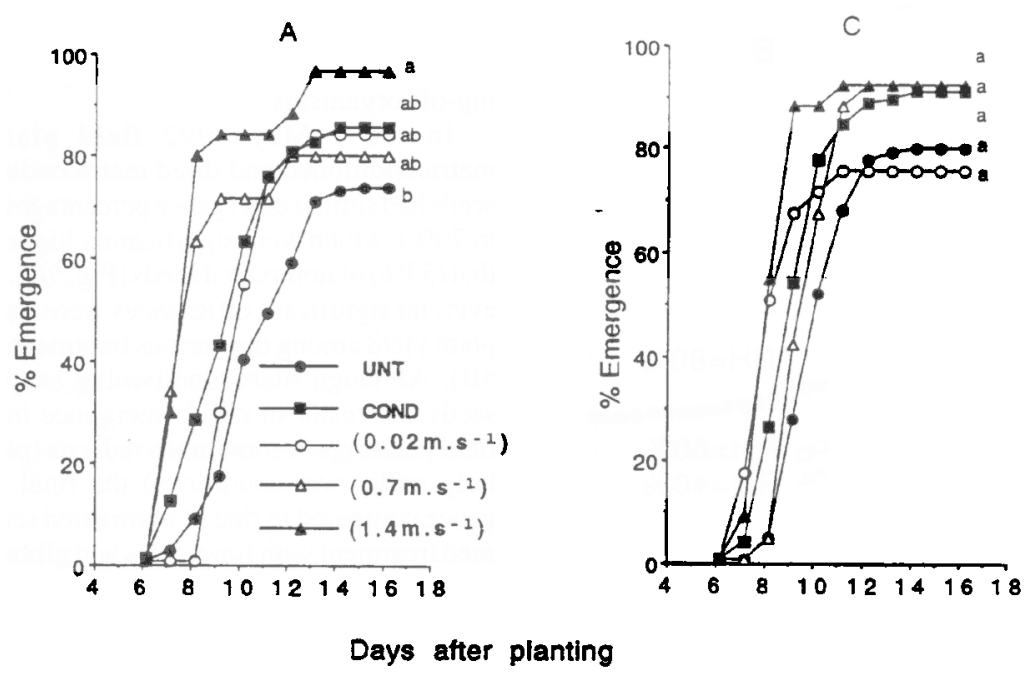

B

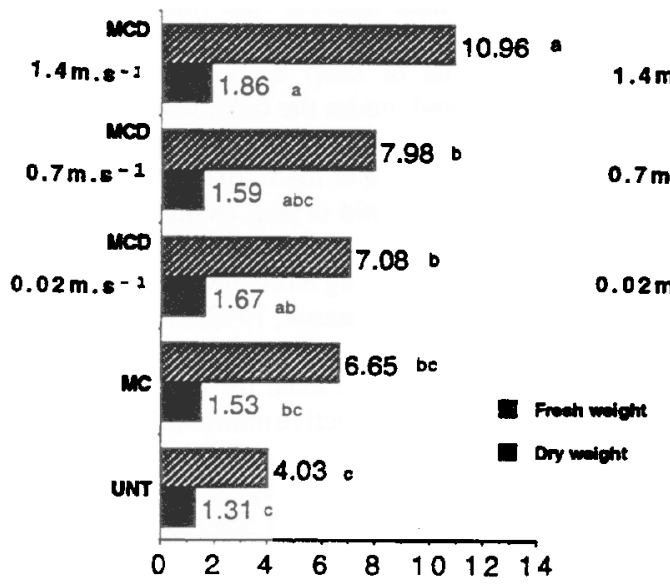

Weight of shoots, $\mathrm{g}$

Fig. 4. (A) Emergence and (B) fresh and dry shoot weight of matriconditioned snap bean seeds planted, with or without drying, to a final moisture content of $15 \%$ (wet basis). (C) Emergence and (D) fresh and dry shoot weight of matriconditioned seeds planted, with or without drying, to a final moisture content of $22 \%$. Shoot weight was determined 16 days after planting. Mean separation of emergence percentages $(A$ and $\mathbf{C})$ and fresh and dry weights (B and D) by analysis of variance and Duncan's multiple range test $(\alpha=0.05)$. UNT $=$ nontreated, $\mathrm{MC}=$ matriconditioned, $\mathrm{MCD}=$ matriconditioned and then dried.
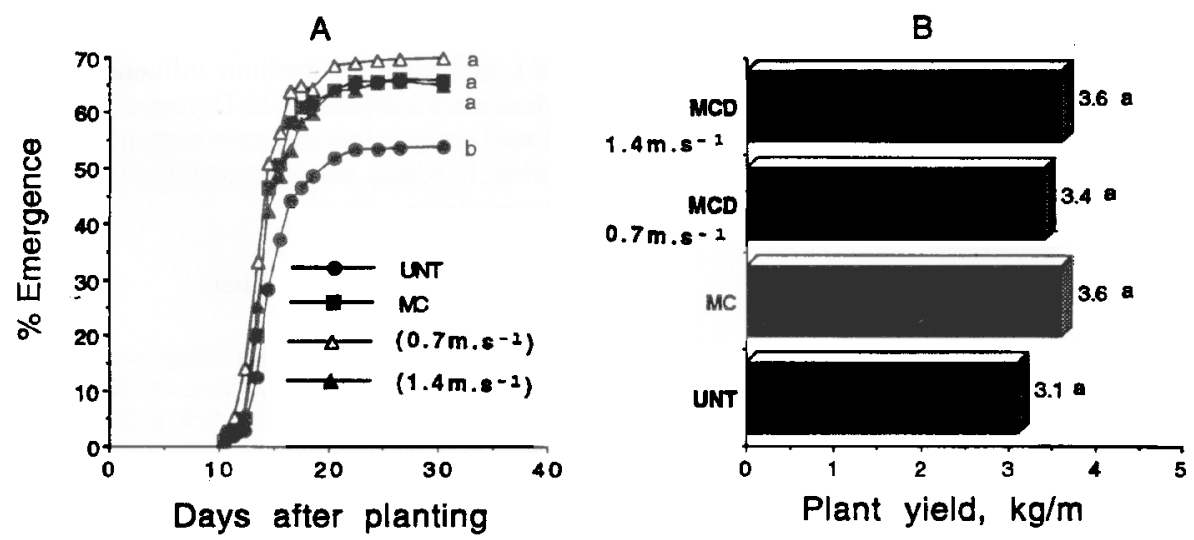

Fig. 5. (A) Emèrgence and (B) plant yield following 1 May 1992 field planting of matriconditioned and matriconditioned plus dried [final moisture content, $15 \%$ (wet basis)] snap bean seeds. Emergence and yield (root, shoot, and pod weight) were determined 30 and 70 days after planting, respectively. Mean separation of emergence percentages and plant yield by analysis of variance and Duncan's multiple range test $(\alpha=0.05)$. UNT $=$ nontreated, $\mathrm{MC}=$ matriconditioned, $\mathrm{MCD}=$ matriconditioned and then dried.
Grabe, D.F. 1989. Measurement of seed moisture, p. 69-90. In: P.C. Stanwood and M.B. McDonald (eds.). Seed moisture. Crop Sci. Soc. Amer., Madison, Wis. Spec. Publ. 14.

Heydecker, W. and P. Coolbear. 1977. Seed treatments for improved performance-survey and attempted prognosis. Seed Sci. Technol. 5:353425 .

Huizhen, L. and R.V. Mercy. 1984. Thin layer drying of yellow dent corn. Trans. Amer. Soc. Agr. Eng. 27:581-585.

Khan, A.A. 1992. Preplant physiological seed conditioning. Hort. Rev. 13:131-181.

Khan, A.A., J.D. Maguire, G.S. Abawi, and S. Ilyas. 1992. Matriconditioning of vegetable seeds to improve stand establishment in early field plantings. J. Amer. Soc. Hort. Sci. 117:41-47.

Khan, A.A., H. Miura, J. Prusinski, and S. Ilyas. 1990. Matriconditioning of seeds to improve seedling emergence. Proc. Natl. Symp. Stand Establishment Hort. Crops., Minneapolis. p. 1940.

Khan, A.A., N.H. Peck, and C. Samimy. 1980/81. Seed osmoconditioning: Physiological and biochemical changes. Israel J. Bot. 29:133-144.

Khan, A.A. and W. Ptasznik. 1992. Integrating matriconditioning of snap bean seeds with pesticides, hormones and drying treatments. Proc. Natl. Symp. Stand Establishment Hort. Crops, Ft. Myers, Fla. p. 101-1 13.

Khan, A.A., K.-L. Tao, J.S. Knypl, B. Borkowska, and L.E. Powell. 1978. Osmotic conditioning of seeds: Physiological and biochemical changes. Acta Hort. 83:267-278.

Knypl, J. and A.A. Khan. 1981. Osmoconditioning of soybean seeds to improve performance at suboptimal temperatures. Agron. J. 73:112-116.

Kubik, K.K., J.A. Eastin, J.D. Eastin, and K.M. Eskridge. 1988. Solid matrix priming of tomato and pepper. Proc. Intl. Conf. Stand Establishment Hort. Crops, Lancaster, Pa. p. 86-96.

Misra, M.K. and D.B. Brooker. 1980. Thin-layer drying and rewetting equation for shelled yellow corn. Trans. Amer. Soc. Agr. Eng. 23:12541260 .

Nienow, A.W., W. Bujalski, G.M. Petch, D. Gray, and R.L.K. Drew. 1991. Bulk priming and drying of leek seeds: The effects of two polymers of polyethylene glycol and fluidized bed drying. Seed Sci. Technol. 19: 107-1 16.

Parera, C.A. and D.J. Cantliffe. 1992a. Enhanced emergence and seedling vigor in shrunken-2 sweet corn via seed disinfection and solid matrix priming. J. Amer. Soc. Hort. Sci. 117:400-403.

Parera, C.A. and D.J. Cantliffe. 1992b. Presowing seed treatments to enhance seedling quality of supersweet corn. Proc. Natl. Symp. Stand Establishment Hort. Crops, Ft. Myers, Fla. p. 131137.

Ptasznik, W., J. Barnard, and A.A. Khan. 1992. Development of a drying procedure following matriconditioning of snap bean seeds, p. 13411349. In: A.S. Mujumdar (ed.). Drying '92. Elsevier Science publisher, B.V., Amsterdam.

SAS Institute. 1990. SAS/STAT user's guide. version 6. 4th ed. SAS Institute, Cary, N.C. 